\title{
KARAKTERISTIK TANAH HAHT (HUMAN ALTERED-HUMAN TRANSPORTED) DI AREA PERDESAAN TERHADAP KELESTARIAN LINGKUNGAN \\ Characteristics of HAHT (Human Altered-Human Transported) Soil in Rural Areas for Environmental Sustainability
}

\author{
Ahmad Fauzan Adzima1 $^{1}$, Muhammad Anggri Setiawan²,3, Djati Mardiatno ${ }^{2}$ \\ ${ }^{1}$ Program Magister S2 Geografi, Fakultas Geografi Universitas Gadjah Mada. \\ ${ }^{2}$ Laboratorium Geomorfologi Lingkungan dan Mitigasi Bencana, Fakultas Geografi, \\ Universitas Gadjah Mada. \\ ${ }^{3}$ Kelompok Peneliti Transbulent. \\ E-mail:fauzanadzima65@gmail.com
}

DOI: $10.31314 /$ jsig.v2i2.373

Abstract - HAHT (Human Altered-Human Transported) soil is soil formed as a result of anthropogenic intervention. The land developed following the pattern of human needs that were suspected of having various problems and impacting the environment sustainability. The purpose of this study is to analyze the effect of HAHT soil characteristics on environmental sustainability. The method used in this research is survey and laboratory test. The results showed that human intervention has a real influence on the soil. HAHT soil characteristics ultimately affect soil function and adversely affect environmental sustainability.

Keywords : HAHT soil, soil characteristic, environmental sustainability.

\begin{abstract}
Abstrak - Tanah HAHT (Human Altered-Human Transported) merupakan tanah yang terbentuk hasil intervensi antropogenik. Tanah tersebut berkembang mengikuti pola kebutuhan manusia yang dicurigai memiliki berbagai permasalahan dan berdampak terhadap kelestarian lingkungan. Tujuan penelitian ini yaitu menganalisis pengaruh karakteristik tanah HAHT terhadap kelestarian lingkungan. Metode yang digunakan dalam penelitian ini yaitu survei dan uji laboratorium. Hasil penelitian menunjukkan bahwa Intervensi yang dilakukan manusia telah memberikan pengaruh yang nyata terhadap tanah. Karakteristik tanah HAHT pada akhirnya memengaruhi fungsi tanah dan berdampak buruk terhadap kelestarian lingkungan di lokasi penelitian
\end{abstract}

Kata kunci: tanah HAHT, karakteristik tanah, kelestarian lingkungan. 


\section{PENDAHULUAN}

Tanah HAHT (Human Altered-Human Transported) merupakan tanah yang terbentuk akibat adanya intervensi berupa faktor antropogenik. Tanah ini tersebar luas diseluruh dunia dan terkonsentrasi dekat tempat orang bermukim dan bekerja (Galbraith, 2018). Saat ini diperkirakan bahwa lebih dari 50\% wilayah di permukaan Bumi telah terganggu oleh aktivitas manusia (Hooke et al., 2012). Pemanfaatan sumberdaya lahan saat ini berkembang mengikuti pola kebutuhan manusia. Pemotongan lereng untuk jalan, pemadatan tanah untuk konstruksi, penambangan serta aktivitas lainnya yang tidak didasari dengan manajemen yang baik merupakan faktor utama terjadinya degradasi lahan. Proses tersebut telah mempercepat laju erosi dan sedimentasi (Li et al., 2017), yang berdampak terhadap turunnya kualitas tanah (Surni et al., 2015).

Penurunan kualitas tanah merupakan indikasi adanya ancaman yang besar terhadap ekosistem fauna dalam tanah (Scanlon et al., 2005; Alessandra et al., 2007; Matsa, 2011; Ibrahim, 2014). Kehilangan biodiversitas dalam tanah dapat menyebabkan beberapa permasalahan, diantaranya yaitu (1) pengurangan fungsi tanah dalam menyediakan makanan bagi tanaman; (2) Berkurangnya siklus nutrisi dan fiksasi nitrogen; (3) Berkurangnya daya tahan tanah untuk menahan beban; (4) Pengurangan daur ulang sampah organik; (5) Mengurangi laju infiltrasi; (6) Mengurangi kapasitas bioremediasi; (7) Struktur tanah terhambat; dan (8) Memiliki dampak yang besar terhadap keanekaragaman hayati yang ada di luar tanah (Montanarella, 2007).

Antropedogenesis berkembang pesat di wilayah urban, namun pada kenyataannya hal tersebut juga terjadi di wilayah perdesaan utamanya yang memiliki morfologi perbukitan. Salah satunya adalah Desa Margoyoso, Kecamatan Salaman, Kabupaten Magelang, Jawa Tengah. Secara umum Desa Margoyoso telah mengalami intervensi manusia secara intensif dengan bukti keberadaan morfologi yang telah dimodifikasi (Gambar 1). Bentuk intervensi di Desa ini tergolong kedalam Agrogenic, Urbanogenic, Traffic, dan Water management (Adzima et al., 2019). Bentuk intervensi tersebut menghasilkan kelas tanah HAHT yang berbeda dan memiliki pengaruh terhadap kualitas dan keberadaan fauna tanah (Adzima, 2019). Tujuan penelitian ini yaitu menganalisis karakteristik tanah HAHT terhadap kelestarian lingkungan.
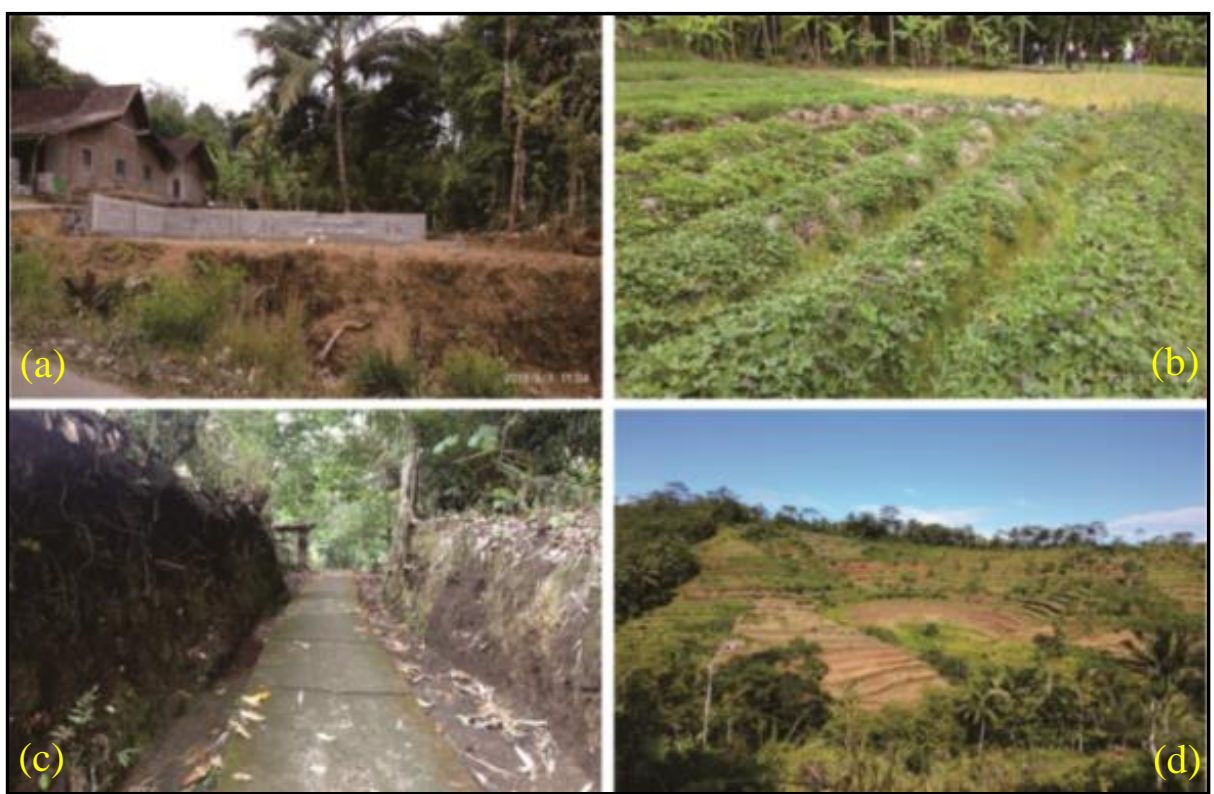

Gambar 1. Bentuk modifikasi morfologi di Sub DAS Bompon (a) pemotongan dan perataan lereng untuk konstruksi rumah; (b) peninggian tanah untuk tegalan; (c) pemotongan lereng untuk konstruksi jalan; dan (d) pembuatan teras.

\section{METODE DAN DATA}

Penelitian ini dilakukan di Desa Margoyoso, Kecamatan Salaman, Kabupaten Magelang, Jawa Tengah. Lokasi penelitian masuk kedalam bagian Laboratorium Alam Transbulent di Sub DAS Bompon. Metode yang digunakan dalam penelitian ini yaitu survei dan uji laboratorium. Bahan yang digunakan adalah Peta Tanah HAHT skala 1:2.000 (Gambar 2). Survei dilakukan 
berdasarkan kelas tanah HAHT yaitu di tanah Anthroportic Portents (ApP), Anthrodensic Portents (AdP), dan Anthraltic Cavalteps (AtC) (Adzima, 2019). Masing-masing kelas tanah dilakukan pembukaan profil untuk kemudian dilakukan pengamatan morfologi tanah dan jenis makrofauna yang ada. Selanjutnya setiap kelas tanah diambil sampel tanahnya untuk dilakukan pengujian karakteristik fisik berupa tekstur dan berat volume (BV) dan karakteristik kimia tanah berupa pH H2O, bahan organik, KPK, kation tertukar $(\mathrm{Ca}, \mathrm{Mg}, \mathrm{K}$, dan $\mathrm{Na}$ ), dan Kejenuhan Basa di laboratorium. Data karakteristik tanah kemudian di hubungkan dengan fungsi tanah sebagai penyedia nutrisi bagi tanaman, pengendali erosi, pengendali carbon, habitat bagi fauna, dan penyimpan air.

\section{HASIL DAN PEMBAHASAN}

\subsection{Karakteristik Fisik}

Hasil uji tanah di laboratorium, menunjukkan bahwa kelas tekstur yang dominan adalah lempung dengan persentase angka berada di kisaran harkat sedang hingga tinggi yaitu 31,22 68,45\% (Tabel 1). Profil pewakil AtC (Anthraltic Cavalteps) memiliki persentase lempung dengan harkat tinggi sedangkan ApP (Anthroportic Portents) dan AdP (Anthrodensic Portents) memiliki persentase lempung sedang. Intervensi manusia terbukti telah memberikan dampak berupa penurunan fraksi lempung dalam tanah. Penurunan tersebut disebabkan karena adanya tambahan bahan manufaktur yang terangkut ke tanah. bahan tersebut merupakan material yang berbeda dengan bahan induk aslinya dan dapat mengubah karakteristik tanah, utamanya tekstur. Proses addition berupa penambahan pasir dan bata pada tanah menyebabkan fraksi lempung berkurang dan fraksi pasir meningkat.

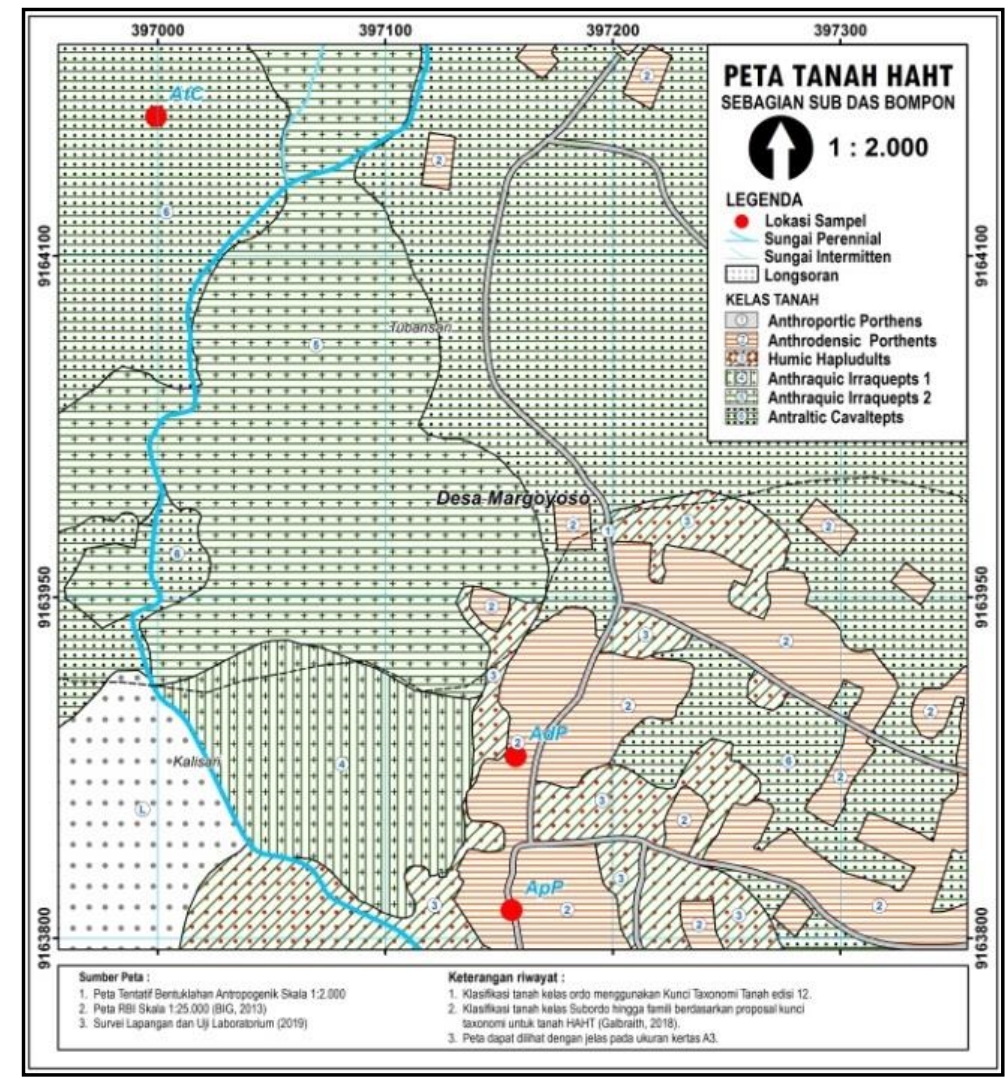

Gambar 2. Lokasi Penelitian (Sumber: Adzima, 2019)

Nilai berat volume pada tanah mengindikasikan bahwa telah terjadi proses pemadatan tanah di profil ApP dan AdP yang disebabkan oleh faktor antropogenik. Aktivitas manusia berupa konstruksi jalan dan rumah menyebabkan tanah memperoleh tekanan yang lebih besar dan berbeda dengan keadaan sebelumya. Gambar 3 berikut menunjukkan fraksi pasir yang mengalami penambahan bahan manufaktur buatan manusia. 


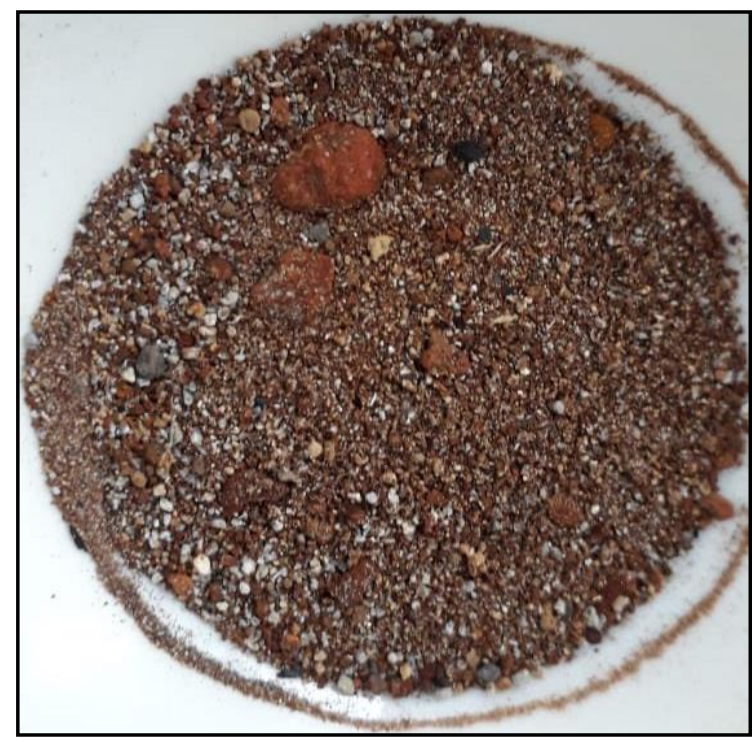

Gambar 3. Fraksi pasir yang mengalami penambahan material pasir dan bata

Karakteristik fisika tanah selengkapnya dapat dilihat pada Tabel 1 di bawah ini:

Tabel 1. Karakteristik fisika tanah profil pewakil (Sumber : Hasil analisis, 2019).

\begin{tabular}{|c|c|c|c|c|c|c|c|}
\hline \multirow{2}{*}{$\mathbf{P}$} & \multirow{2}{*}{ Intervensi } & \multirow{2}{*}{$\mathbf{H}$} & \multirow{2}{*}{$\begin{array}{c}\text { BV } \\
(\mathrm{g} / \mathrm{cm} 3)\end{array}$} & \multicolumn{3}{|c|}{ Fraksi (\%) } & \multirow{2}{*}{ Tekstur } \\
\hline & & & & Pasir & Debu & Lempung & \\
\hline \multirow{6}{*}{ 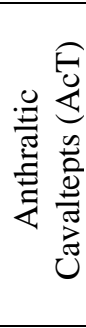 } & \multirow{6}{*}{$\begin{array}{l}\text { Agrogenic } \\
\text { (Teras) }\end{array}$} & Ap1 & 0,87 & 9,03 & 27,52 & 63,46 & Lempung \\
\hline & & Ap2 & 0,87 & 6,77 & 30,73 & 62,50 & Lempung \\
\hline & & $\mathrm{A} / \mathrm{B}$ & 0,73 & 7,35 & 28,62 & 64,04 & Lempung \\
\hline & & $\mathrm{Bw}$ & 0,80 & 6,54 & 35,03 & 58,43 & Lempung \\
\hline & & Btb & 0,84 & 6,78 & 24,77 & 68,45 & Lempung \\
\hline & & Bwb & 0,81 & 5,95 & 30,33 & 63,72 & Lempung \\
\hline \multirow{5}{*}{ 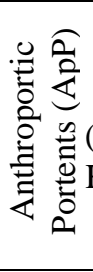 } & \multirow{5}{*}{$\begin{array}{c}\text { Traffic } \\
\text { (Pemotongan dan } \\
\text { Konstruksi Jalan) }\end{array}$} & $\wedge^{\wedge}$ Aup & 1,06 & 20,22 & 31,34 & 48,44 & Lempung \\
\hline & & ${ }^{\wedge} \mathrm{Cu} 1$ & 1,12 & 23,40 & 31,15 & 45,45 & Lempung \\
\hline & & ${ }^{\wedge} \mathrm{Cu} 2$ & 1,03 & 23,55 & 26,73 & 49,72 & Lempung \\
\hline & & $2 \mathrm{Bdb}$ & 1,20 & 23,11 & 27,90 & 48,99 & Lempung \\
\hline & & $2 \mathrm{Bwb}$ & 1,10 & 36,47 & 29,60 & 33,93 & Geluh Lempungan \\
\hline \multirow{6}{*}{ 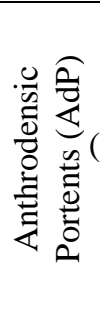 } & \multirow{6}{*}{$\begin{array}{l}\text { Urbanogenic } \\
\text { Pemotongan dan } \\
\text { Konstruksi } \\
\text { Rumah) }\end{array}$} & ${ }^{\wedge} \mathrm{Cu}$ & 1,02 & 19,99 & 24,4 & 55,61 & Lempung \\
\hline & & $\mathrm{Bdx} 1$ & 1,17 & 20,08 & 22,06 & 57,86 & Lempung \\
\hline & & $\mathrm{Bd} \times 2$ & 1,21 & 34,06 & 24,47 & 41,48 & Lempung \\
\hline & & Bdx3 & 1,19 & 34,39 & 29,86 & 35,75 & Lempung \\
\hline & & $\mathrm{Bw}$ & 0,84 & 14,93 & 53,85 & 31,22 & Geluh Lempung Debuan \\
\hline & & $\mathrm{Bt}$ & 1,00 & 27,63 & 26,49 & 45,88 & Lempung \\
\hline
\end{tabular}

\subsection{Karakteristik Kimia}

Berdasarkan Tabel 2, profil pewakil di lokasi penelitian memiliki $\mathrm{pH}_{2} \mathrm{O}$ dengan harkat masam hingga agak masam. Profil ApP dan AdP merupakan profil dengan nilai $\mathrm{pH}$ yang lebih rendah dibanding yang lainnya. Pengaruh intervensi manusia dalam memanfatkan sumberdaya lahan merupakan faktor yang memengaruhi nilai $\mathrm{pH}$ di profil tersebut. Penambahan bahan manufaktur telah meningkatkan fraksi pasir pada tanah sehingga proses pelindian lebih cepat. Proses pelindian menyebabkan kation basa di profil ini tercuci sehingga ion $\mathrm{H}^{+}$pada tanah meningkat. Hardjowigeno (2007) menyatakan bahwa pada tanah dengan $\mathrm{pH}$ masam memiliki ion $\mathrm{H}^{+}$yang lebih tinggi daripada ion $\mathrm{OH}^{-}$. Karakteristik kimia tanah dapat dilihat pada Tabel 2 berikut: 
Tabel 2. Karakteristik kimia tanah profil pewakil. (Sumber: Hasil analisis, 2019).

\begin{tabular}{|c|c|c|c|c|c|c|c|c|c|c|c|}
\hline \multirow{2}{*}{$\mathbf{P}$} & \multirow{2}{*}{ Intervensi } & \multirow{2}{*}{$\mathbf{H}$} & \multirow{2}{*}{$\begin{array}{c}\mathbf{p H} \\
\left(\mathbf{H}_{2} \mathrm{O}\right)\end{array}$} & \multirow{2}{*}{$\begin{array}{c}\text { BO } \\
\%\end{array}$} & \multirow{2}{*}{$\begin{array}{c}\mathrm{KPK} \\
\mathrm{Cmol} / \mathrm{kg}\end{array}$} & \multicolumn{4}{|c|}{ Kation tertukar } & \multirow{2}{*}{$\begin{array}{l}\Sigma \text { Kation } \\
\text { tertukar }\end{array}$} & \multirow{2}{*}{$\begin{array}{c}\text { KB } \\
\%\end{array}$} \\
\hline & & & & & & $\mathrm{Ca}$ & Mg & $\mathbf{K}$ & $\mathbf{N a}$ & & \\
\hline \multirow{6}{*}{ 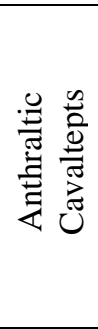 } & \multirow{6}{*}{$\begin{array}{c}\text { Agrogenic } \\
\text { (Teras) }\end{array}$} & Ap1 & 5,81 & 3,32 & 21,20 & 1,16 & 0,72 & 1,56 & 0,11 & 3,55 & \multirow{6}{*}{13,22} \\
\hline & & Ap2 & 5,98 & 2,61 & 20,80 & 0,94 & 0,50 & 1,13 & 0,15 & 2,72 & \\
\hline & & $\mathrm{A} / \mathrm{B}$ & 6,02 & 1,94 & 20,80 & 0,92 & 0,48 & 1,07 & 0,16 & 2,63 & \\
\hline & & $\mathrm{Bw}$ & 6,14 & 1,47 & 23,20 & 0,89 & 0,41 & 1,06 & 0,2 & 2,56 & \\
\hline & & Btb & 5,96 & 1,31 & 22,80 & 0,96 & 0,44 & 1,36 & 0,21 & 2,97 & \\
\hline & & Bwb & 5,86 & 1,42 & 24,00 & 1,07 & 0,44 & 1,35 & 0,21 & 3,07 & \\
\hline \multirow{5}{*}{ 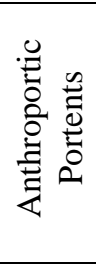 } & \multirow{5}{*}{$\begin{array}{c}\text { Traffic } \\
\text { (Pemotongan } \\
\text { dan Konstruksi } \\
\text { Jalan) }\end{array}$} & $\wedge$ Aup & 5,45 & 2,52 & 20,00 & 0,23 & 0,58 & 0,19 & 0,02 & 1,02 & \multirow{5}{*}{5,63} \\
\hline & & ${ }^{\wedge} \mathrm{Cu} 1$ & 5,21 & 1,85 & 18,00 & 0,35 & 0,41 & 0,11 & 0,02 & 0,90 & \\
\hline & & ${ }^{\wedge} \mathrm{Cu} 2$ & 5,30 & 2,45 & 17,60 & 0,31 & 0,61 & 0,10 & 0,02 & 1,04 & \\
\hline & & $2 \mathrm{Bdb}$ & 5,36 & 1,83 & 19,20 & 0,38 & 0,50 & 0,10 & 0,02 & 1,00 & \\
\hline & & $2 \mathrm{Bwb}$ & 5,25 & 1,20 & 16,00 & 0,29 & 0,69 & 0,11 & 0,02 & 1,11 & \\
\hline \multirow{6}{*}{ 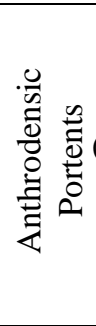 } & \multirow{6}{*}{$\begin{array}{c}\text { Urbanogenic } \\
\text { (Pemotongan dan } \\
\text { Konstruksi } \\
\text { Rumah) }\end{array}$} & ${ }^{\wedge} \mathrm{Cu}$ & 5,18 & 1,86 & 18,80 & 0,18 & 0,60 & 0,61 & 0,02 & 1,41 & \multirow{6}{*}{9,62} \\
\hline & & $\mathrm{Bdx} 1$ & 4,99 & 1,26 & 17,20 & 0,18 & 0,74 & 0,67 & 0,02 & 1,61 & \\
\hline & & $\mathrm{Bdx} 2$ & 4,94 & 1,24 & 15,20 & 0,19 & 0,82 & 0,68 & 0,02 & 1,71 & \\
\hline & & Bdx3 & 4,93 & 1,24 & 16,00 & 0,15 & 0,69 & 0,54 & 0,02 & 1,40 & \\
\hline & & Bwc & 4,67 & 1,32 & 17,60 & 0,15 & 0,79 & 1,04 & 0,03 & 2,01 & \\
\hline & & $\mathrm{Bt}$ & 4,60 & 1,35 & 18,40 & 0,14 & 0,72 & 0,85 & 0,03 & 1,74 & \\
\hline
\end{tabular}

Kandungan bahan organik tergolong kedalam harkat sangat rendah hingga rendah. Rendahnya BO dan adanya penurunan fraksi lempung di profil ApP dan AdP menyebabkan nilai KPK tanah menjadi rendah. Nilai KPK tanah pada dasarnya berasal dari bahan penyusunnya, kemudian dikontrol oleh jerapan koloid humus dan lempung. Soares et al, (2005), menyatakan bahwa pertukaran kation yang terjadi dalam tanah difokuskan pada kandungan lempung dan bahan organik. Selain itu Capra et al. (2012), juga ikut membenarkan bahwa penurunan fraksi lempung dalam tanah menjadi faktor rendahnya KPK dalam tanah. Persentase kejenuhan basa (KB) dilokasi penelitian menunjukkan harkat yang sangat rendah. Pada dasarnya persentase KB menunjukkan sejauh mana tingkat pelindian yang terjadi dalam tanah (Hardjowigeno, 2016).

Nilai KB yang sangat rendah di profil pewakil mengindikasikan bahwa telah terjadi proses pelindian yang intensif. Hal tersebut dikuatkan dengan tingginya curah hujan dan adanya dominasi kation asam dilokasi penelitian. Pada dasarnya tanah di lokasi penelitian, baik itu Tubansari maupun Kalisari memiliki KB $<35 \%$. Hal tersebut dipengaruhi oleh adanya alterasi hidrotermal (Gambar 4) yang menyebabkan tanah didominasi oleh mineral sekunder berupa kaolinit (Budianto, 2016; Pratiwi, 2017; Sartohadi et al,. 2018). Modifikasi tanah yang dilakukan oleh manusia kemudian menurunkan KB ke harkat yang sangat rendah.

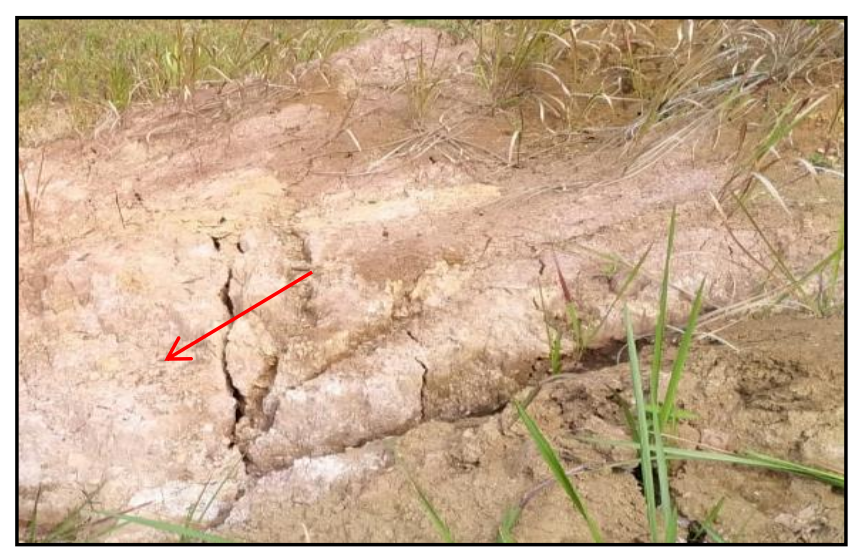

Gambar 4. Tanah hasil proses alterasi hidrotermal. (tanda panah merah menunjukkan ciri kaolinit di lokasi penelitian) 


\subsection{Pengaruh Karakteristik Tanah HAHT terhadap kelestarian Lingkungan.}

Karakteristik tanah di lokasi penelitian menggambarkan bahwa telah terjadi penurunan kualitas tanah utamanya pada Kelas tanah HAHT Anthroportic Portents (Intervensi Traffic) dan Anthrodensic Portents (Intervensi Urbanogenic) (Tabel 1 dan 2), sehingga degradasi lahan tidak dapat dihindari. Penurunan kualitas memberikan gambaran bahwa telah terjadi pengurangan nutrisi dalam tanah sehingga tanaman tidak memperoleh unsur yang dibutuhkan. Hal ini dapat dilihat dari \%KB di lokasi penelitian yang memiliki harkat sangat rendah hingga rendah (Tabel 2). Kejenuhan Basa merupakan suatu indikasi kesuburan bagi tanah. semakin besar nilai KB maka kesuburan tanah semakin baik (Tan, 1991).

Berdasarkan Tabel 1, Intervensi yang dilakukan manusia berupa pemotongan dan perataan lereng untuk konstruksi rumah dan jalan telah memberikan dampak berupa pemadatan tanah. Proses pemadatan menyebabkan pori makro maupun mikro menjadi tertutup sehingga menghambat proses infiltrasi. Selain itu, aliran permukaan cenderung akan meningkat dan memiliki potensi erosi yang sangat besar (Ghosh, 2013). Konversi lahan dengan melakukan pemotongan lereng menyebabkan tegakan pohon berkurang. Tanah yang tidak tertutup vegetasi secara langsung akan menerima sinar matahari dan hujan yang menyebabkan suhu dan kelembaban pada tanah ikut berubah. Umumnya suhu yang tinggi dan curah hujan yang rendah di lahan kering menyebabkan pembentukan bahan organik sangat lambat sehingga akan berpengaruh terhadap keanekaragaman makrofauna dalam tanah.

Tabel 3, menunjukkan bahwa keberagaman makrofauna dalam tanah mengikuti kondisi abiotik tanah berupa $\mathrm{pH}$ dan $\mathrm{C}$-organik. Hal ini disebabkan karena keberadaan fauna tanah sangat dipengaruhi oleh kondisi biotik dan abiotik suatu lingkungan. Tanah dengan kandungan bahan organik yang tinggi merupakan habitat yang ideal bagi makrofauna. Rousseau et al. (2013) dalam penelitiannya mengatakan bahwa makrofauna tanah merupakan indikator yang paling sensitif sehingga dapat digunakan untuk menduga kualitas lahan.

Tabel 3. Keanekaragaman makrofauna pada kelas tanah HAHT. (Sumber : Survei, 2019)

\begin{tabular}{cccc}
\hline \multirow{2}{*}{ Jenis Makrofauna } & \multicolumn{3}{c}{ Kelas Tanah HAHT } \\
\cline { 2 - 4 } & Anthraltic Cavaltepts & Anthroportic Portents & Anthrodensic Portents \\
\hline Rayap & 14 & 5 & - \\
Cacing tanah & 6 & - & $^{*}$ \\
Larva serangga & 1 & - & - \\
Semut & 6 & - & - \\
Keong & - & - & - \\
Jumlah & $\mathbf{2 6}$ & $\mathbf{5}$ & $\mathbf{9}$ \\
$\boldsymbol{\Sigma}$ Jenis & $\mathbf{4}$ & $\mathbf{1}$ & \\
\hline & & Kondisi Abiotik & 4,9 \\
\hline pH & 6,0 & 5,4 & 0,8 \\
\hline C-Organik & 1,2 & 1,1 &
\end{tabular}

Keterangan $=(*)$ hanya terdapat di permukaan bekas pembakaran.

Secara umum faktor pembentuk tanah yang sama memiliki karakteristik tanah yang sama dengan jenis ordo tanah yang sama. Keberadaan makrofauna pada profil ApP dan AdP yang hanya terdapat 1 jenis mengindikasikan telah terjadi perubahan karakteristik tanah yang signifikan dan berbeda dengan kondisi awalnya. Pada profil tanah ApP terdapat makrofauna jenis rayap. Keberadaan rayap hanya ditemukan pada horizon ${ }^{\wedge} \mathrm{Cu} 2$ yang terdapat potongan akar pohon kelapa. Pada profil tanah AdP ditemui cacing dengan jumlah yang banyak akan tetapi nilai $\mathrm{pH}$ menunjukkan tingkatan asam dan kandungan $\mathrm{C}$ Organik sangat rendah. Hal ini sangat dimungkinkan terjadi mengingat permukaan tanah terdapat artefak berupa arang pembakaran. Keberadaan cacing tanah hanya terdapat pada arang pembakaran saja dan tidak ditemui di dalam tanah. Pemadatan yang terjadi pada tanah sampai kedalaman $100 \mathrm{~cm}$ membuat tanah tidak memperoleh tambahan bahan organik, selain itu pemadatan menyebabkan tanah menjadi keras dan sulit ditembus oleh cacing maupun akar tanaman. 


\section{KESIMPULAN}

Intervensi yang dilakukan manusia telah memberikan pengaruh yang nyata terhadap tanah. Karakteristik tanah HAHT pada akhirnya memengaruhi fungsi tanah dan berdampak buruk terhadap kelestarian lingkungan.

\section{DAFTAR PUSTAKA}

Adzima, F., 2019. Pemetaan Tanah HAHT (Human Altered-Human Transported) pada Skala Detail di Sub DAS Bompon. Tesis Program Studi S2 Geografi, Fakultas Geografi, Universitas Gadjah Mada.

Adzima, F., Setiawan, A., Mardiatno, D., 2019. Classification of Anthropogenic Landforms in the Rural area: Study case Bompon Catchment. Submitted The 3rd International Conference on Environmental Resources Management in Global Region, Yogyakarta.

Alessandra F, Maiorano L, Boitani L., 2007. Changes in land-use/landcover patterns in Italy and their implications for biodiversity conservation. Landscape Ecol (2007) 22: 617-631. DOI: 10.1007/s10980-006-9056-4

Budianto, Y., 2016. Keterdapatan Sensitive Clay Pada Lokasi Longsor Lahan di Sub DAS Bompon, Kabupaten Magelang. Skripsi Program Studi Geografi Lingkungan, Fakultas Geografi, Universitas Gadjah Mada.

Capra, G. F., Vacca, S., Cabula, E., Grilli, E., \& Buondonno, A., 2012. Human-Altered and Human-Transported Soils in an Italian Industrial District. Soil Science Society of America Journal, 76(5), 1828. DOI: 10.2136/sssaj2011.0384

Galbraith, J. M., 2018. Human-Altered and Human-Transported (HAHT) Soils in The U.S. Soil Classification System. Soil Science and Plant Nutrition, 64 (2): 190-199. DOI: 10.1080/00380768.2018.1442682

Hardjowigeno, S., 2007. Ilmu Tanah. Akademika Pressindo. Jakarta

Hardjowigeno, S., 2016. Klasifikasi Tanah dan Pedogenesis. Akademia Pressindo. Bekasi

Hooke, R.LeB., Martin-Duque, J.F., and Pedraza, J., 2012. Land Transformation by Humans. GSA Today Vol 22 (12): 4-10. DOI: 10.1130/GSAT151A.1

Ibrahim, H., 2014. Keanekaragaman Mesofauana Tanah Daerah Pertanian Apel Desa Tulungrejo Kecamatan Bumiaji Kota Batu Sebagai Bioindikator Kesuburan Tanah Dan Bahan Ajar Biologi SMA. Skripsi Pendidikan Biologi, UMM. Malang.

LI Jialin., YANG Lei., PU Ruiliang., LIU Yongchao., 2017. A Review on Anthropogenic Geomorphology. Journal of Geographical Sciences, 27 (1): 109- 128. DOI: $10.1007 / \mathrm{s} 11442-017-1367-7$

Matsa, M. and Muringaniza K., 2011. An Assessment of The Landuse and Land Cover Changes in Shurugwi District, Midlands Province, Zimbabwe. Ethiopian J Environ Stud Manag 4(2). DOI: 10.4314 /ejesm.v4i2.10

Montanarella, L., 2007. Trends in Land Degradation in Europe. an Overview In: Sivakumar M.V.K., Ndiang'ui N. (eds) Climate and Land Degradation. Environmental Science and Engineering (Environmental Science). Springer, Berlin, Heidelberg: pp 83-104.

Pirajno, F., 2009. Hydrothermal Processes and Mineral Systems. Springer, Sydney, NSW, Australia

Pratiwi, E.S., 2017. Integrasi Metode Geofifika dan Geokimia untuk Investigasi Material dan Mekanisme Longsor Tipe Rotational Slide di Sub DAS Bompon, Kabupaten Magelang. Tesis Program Studi S2 Ilmu Fisika, Fakultas MIPA, Universitas Gadjah Mada.

Rousseau L, Fonte SJ, Tellez O, Hoek RVD, Lavelle P., 2013. Soil Macrofauna as Indicator of Soil Quality and Landuse Impact in Smallholder Agroecosystems of Western Nicaragua. Ecological indicators 27:71-82. DOI: 10.1016/j.ecolind.2012.11.020

Sartohadi, J., Harlin Jennie Pulungan, N. A., Nurudin, M., \& Wahyudi, W., 2018. The Ecological Perspective of Landslides at Soils with High Clay Content in the Middle Bogowonto Watershed, Central Java, Indonesia. Applied and Environmental Soil Science, 2018, 1-9. DOI: $10.1155 / 2018 / 2648185$

Scanlon, B.R., Reedy, R.C., Tonestrom, D.A.S., Prudicz, D.E., Dennehy, K.F., 2005. Impact of Landuse and Land Cover Change on Groundwater Recharge and Quality in The Southwestern US. Global Change Biology 11: 1577-1593. DOI: 10.1111/j.1365- 
Adzima, A.F., dkk., 2019 Jurnal Sains Informasi Geografi [JSIG], 2(2):32-39, ISSN 2614-1671

2486.2005.01026.x

Surni., Baja, S., Arsyad, U., 2015. Dinamika Perubahan Penggunaan Lahan, Penutupan Lahan Terhadap Hilangnya Biodiversitas di DAS Tallo, Sulawesi Selatan. Prosiding Seminar Nasional Masyarakat Biodiversitas Indonesia. Volume 1, Nomor 5, Agustus 2015. Halaman: 1050-1055

Soares, M.R., R.F. A. Luis, P. V. Torrado, M. Cooper., 2005. Mineralogy Ion Exchange Properties of The Partide Size Fractions of Some Brazilian Soils in Tropical Humid Areas. Geoderma 125: 355-367. DOI: 10.1016/j.geoderma.2004.09.008

Tan, H.K., 1991. Dasar-Dasar Kimia Tanah. Gajah Mada University Press. Cetakan kedua. Jakarta 